\title{
Neurodegeneration Induced by $\beta$-Amyloid Peptides in vitro: The Role of Peptide Assembly State
}

\author{
Christian J. Pike, ${ }^{1}$ Debra Burdick, ${ }^{2}$ Andrea J. Walencewicz, ${ }^{1}$ Charles G. Glabe, ${ }^{2}$ and Carl W. Cotman ${ }^{1}$ \\ 'Irvine Research Unit in Brain Aging and ${ }^{2}$ Department of Molecular Biology and Biochemistry, University of California, \\ Irvine, California 92717
}

The progressive neurodegeneration of Alzheimer's disease has been hypothesized to be mediated, at least in part, by $\beta$-amyloid protein. A relationship between the aggregation state of $\beta$-amyloid protein and its ability to promote degeneration in vitro has been previously suggested. To evaluate this hypothesis and to define a structure-activity relationship for $\beta$-amyloid, aggregation properties of an overlapping series of synthetic $\beta$-amyloid peptides ( $\beta$ APs) were investigated and compared with $\beta$ AP neurotoxic properties in vitro. Using light microscopy, electrophoresis, and ultracentrifugation assays, we found that few $\beta$ APs assembled into aggregates immediately after solubilization, but that over time peptides containing the highly hydrophobic $\beta 29-35$ region formed stable aggregations. In short-term neuronal cultures, toxicity was associated specifically with those $\beta$ APs that also exhibited significant aggregation. Further, upon the partial reversal of $\beta 1-42$ aggregation, a concomitant loss of toxicity was observed. A synthetic peptide derived from a different amyloidogenic protein, islet amyloid polypeptide, exhibited aggregation but not toxicity, suggesting that $\beta$ AP. induced neurotoxicity in vitro is not a nonspecific reaction to aggregated protein. The correlation between $\beta$ AP aggregation and neurotoxicity was also observed in long-term neuronal cultures but not in astrocyte cultures. These data are consistent with the hypothesis that $\beta$-amyloid protein contributes to neurodegeneration in Alzheimer's disease.

[Key words: Alzheimer's disease, $\beta$-amyloid, neurotoxicity, peptide assembly, aggregation, islet amyloid, hippocampal culture]

Alzheimer's disease (AD) is characterized neuropathologically by senile plaques, cerebrovascular amyloidosis, neurofibrillary tangles, and selective neuronal loss. Classic senile plaques, insoluble extracellular deposits primarily comprised of $\beta$-amyloid protein aggregates, are typically surrounded by dystrophic neurites and thus may facilitate neurodegeneration (Tanzi et al., 1989; Selkoe, 1991). In support of this position, recent evidence suggests that $\beta$-amyloid may contribute to the progressive neuronal loss of $\mathrm{AD}$. Several reports indicate that the familial form of $\mathrm{AD}$ is associated with and presumably may be precipitated

\footnotetext{
Received June 11, 1992; revised Sept. 21, 1992; accepted Oct. 23, 1992.

We express our gratitude to J. Kosmoski for his work in peptide synthesis, Dr. A. Copani for helpful discussions and comments on the manuscript, and R. Monzavi for technical assistance. C.J.P. is supported in part by NIMH Grant MH14599. This study was funded by NIA Grant AG07918.

Correspondence should be addressed to Dr. C. W. Cotman at the above address. Copyright (C) 1993 Society for Neuroscience 0270-6474/93/131676-12\$05.00/0
}

by genctic mutations that yield amino acid substitutions adjacent to the $\beta$-amyloid region of the amyloid precursor protein (APP) (Chartier-Harlin et al., 1991; Goate et al., 1991; Murrell et al., 1991). These changes may facilitate the abnormal proteolysis of APP that is believed to result in $\beta$-amyloid deposition. In addition, $\beta$-amyloid protein has been shown to have neurotoxic properties both in vitro and in vivo.

In general, studies of $\beta$-amyloid's biological activities suggest that it may increase neuronal risk for degeneration and/or may be directly neurotoxic. Thus far, however, data are unavailable to define convincingly either the features of $\beta$-amyloid salient to its degenerative abilities or the mechanism(s) by which it acts. The $\beta$-amyloid protein consists of approximately 42 amino acid residues (Masters et al., 1985b; Kang et al., 1987) and is derived from both extracellular and transmembrane domains of APP, a normally occurring and widely distributed protein (Fig. 1). Soluble, synthetic $\beta$-amyloid peptides ( $\beta$ APs) of varying lengths are reported to yield both trophic and toxic responses on CNS neurons in vitro. Hippocampal cultures treated with both truncated and full-length $\beta$ APs initially exhibit enhanced survival (Whitson et al., 1989, 1990; Yankner et al., 1990) and increased neurite outgrowth (Whitson et al., 1990; Pike et al., $1991 \mathrm{~b}$ ), but after several days in vitro can show greater neuronal degeneration than untreated controls (Yankner et al., 1990). In mature cortical cultures, soluble $\beta \mathrm{APs}$, although not directly toxic, do potentiate the toxicity caused by both exposure to glutamate (Koh et al., 1990; Mattson et al., 1992) and transient glucose deprivation (Copani et al., 1991). In vivo, $\beta$-amyloid is reported to be directly neurotoxic. Introduction of purified senile plaque cores into the rat hippocampus causes focal neuronal damage (Frautschy et al., 1991). Similarly, in vivo injection of $\beta 1-40$ is reported to result in stable $\beta$-amyloid deposits accompanied by localized neurodegeneration (Kowall et al., 1991). This last finding is consistent with the observation that insoluble $\beta$-amyloid prevails within the AD brain (Wisniewski et al., 1989) and underscores the relevance of evaluating the activity of the insoluble form of $\beta$-amyloid.

Recently, several laboratories have reported that various synthetic $\beta$ APs form filamentous, $\beta$-sheet assemblies in vitro (Kirschner et al., 1987; Halverson et al., 1990; Barrow and Zagorski, 1991; Hilbich et al., 1991). The assembly phenomenon is reported to be dependent on the $\mathrm{pH}$ of $\beta \mathrm{AP}$ solutions (Barrow and Zagorski, 1991; Burdick et al., 1992), $\beta$ AP concentration, and length of time in solution (Burdick et al., 1992). Although several $\beta$-amyloid fragments have been reported to form such assemblies, only $\beta$ APs that include a substantial portion of the transmembrane sequence assemble into aggregates that are stable at $\mathrm{pH} 7.4$ and resistant to disruption by SDS (Burdick et 


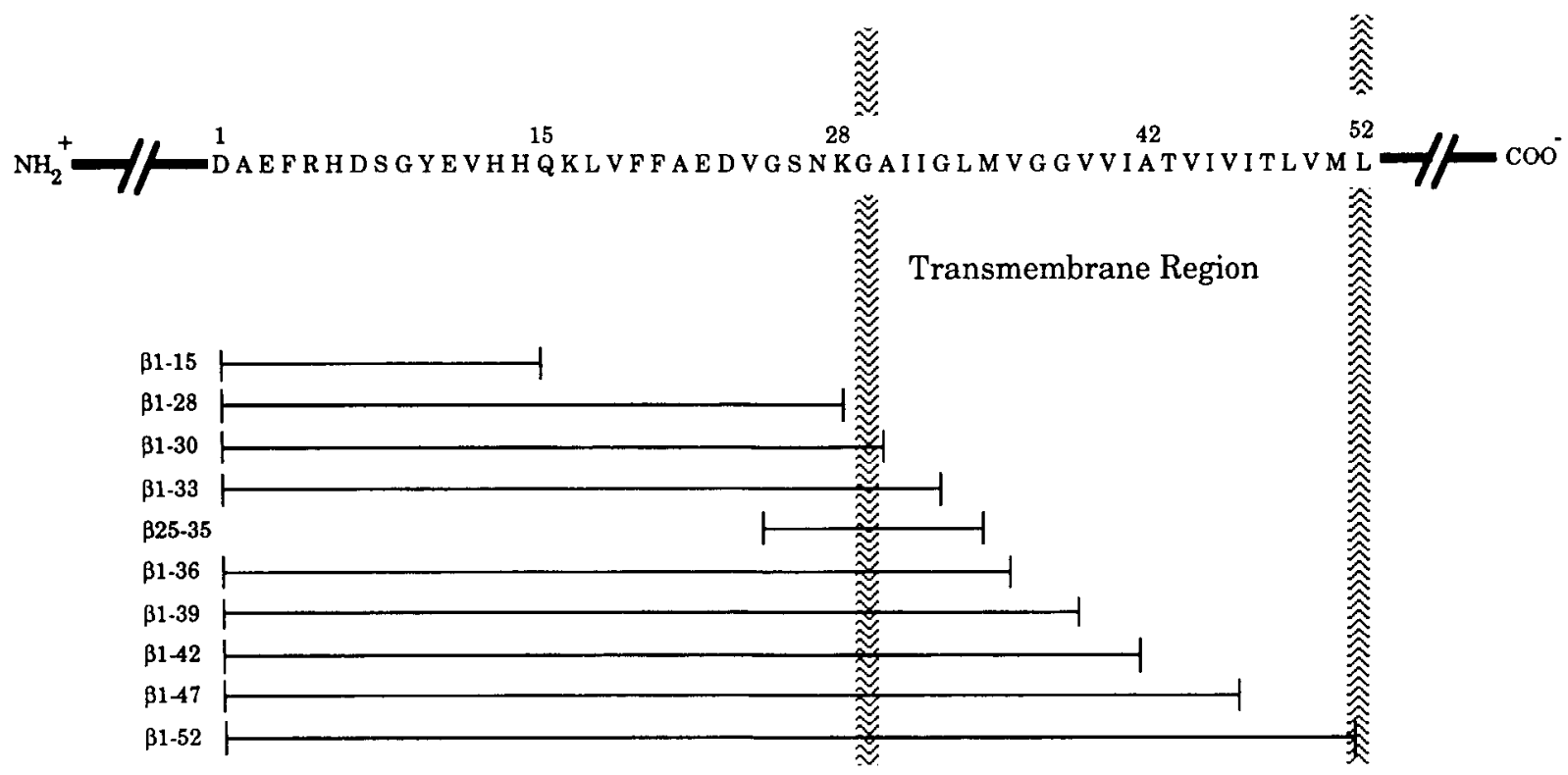

Figure 1. Utilized synthetic peptides correspond to portions of the $\beta$-amyloid protein. APP exists in several isoforms (695-751 amino acid residues), all of which contain the $\beta$-amyloid region that begins approximately 99 residues from the C-terminus (Kang et al., 1987). The 42 amino acid $\beta$-amyloid protein contains both hydrophilic (extracellular residues 1-28) and hydrophobic (transmembrane residues $29-42$ ) domains. In this study, we employed an overlapping series of synthetic $\beta$ APs, ranging from a small 11 residue fragment $(\beta 25-35)$ to peptides extending beyond the full $\beta$-amyloid sequence $(\beta 1-47$ and $\beta 1-52)$.

al., 1992). Thus, interactions between the hydrophobic transmembrane residues have been postulated to function in the stable formation of insoluble $\beta$-amyloid aggregates in vitro and may be related to in vivo amyloid deposition (Hilbich et al., 1991; Burdick et al., 1992).

Recently, we have also observed in vitro formation of insoluble $\beta$-amyloid assemblies, which resulted following incubation of $\beta 1-42$ solutions (Pike et al., 1991b). Further, we reported a change in the biological activity of $\beta 1-42$ solutions after this period of incubation. In agreement with a previous finding (Whitson et al., 1990), we found that initially soluble $\beta 1-42$ enhanced neurite outgrowth in immature hippocampal cultures but was not toxic. However, $\beta 1-42$ that had been preincubated not only exhibited considerable aggregation, but also caused a dose-dependent toxicity (Pike et al., 1991b). Similar incubation of $\beta 1-28$ solutions resulted in neither stable aggregate formation nor toxicity, suggesting that both properties may be specific to hydrophobic $\beta$ APs (Pike et al., 1991a). In addition, we recently reported that the neurites of cultured neurons surround and infiltrate $\beta 1-42$ aggregates and subsequently adopt dystrophic morphology similar to that observed in neurites associated with senile plaques in the AD brain (Pike et al., 1992). Although these findings suggest a potential link between $\beta$ AP assembly and neurotoxicity, this relationship requires further investigation. In this study, we have examined the structure-function relationship between the aggregation and toxic properties of $\beta A P$ s using a series of analogs. The presented data not only support the hypothesis that aggregated forms of $\beta$ APs contribute to neuronal degeneration, but also more clearly define the primary structures necessary for $\beta$-amyloid self-assembly.

\section{Materials and Methods}

Synthetic peptides. Peptides were synthesized by solid-phase F-moc amino acid substitution and purified by reverse-phase HPLC, as described elsewhere (Burdick et al., 1992). As previously discussed, high peptide purity was attained by use of high coupling efficiencies during synthesis, and confirmed by peptide sequencing and electrospray mass spectrometry analyses following purification (Burdick et al., 1992). Peptides were lyophilized as $\mathrm{HCl}$ salts and stored in aliquots at $-20^{\circ} \mathrm{C}$ until solubilization at a concentration of $250 \mu \mathrm{M}$ in double-deionized water $\left(\mathrm{ddH}_{2} \mathrm{O}\right)$. Selected samples of $\beta 25-35$ were solubilized at $2.5 \mathrm{~mm}$ in $35 \%$ acetonitrile, $0.1 \%$ trifluoroacetic acid (TFA) and $\mathrm{ddH}_{2} \mathrm{O}$. Due to solubility constraints, the $\beta 1-47$ and $\beta 1-52$ peptides were initially solubilized at a concentration of $40 \mathrm{mg} / \mathrm{ml}$ in 1,1,1,3,3,3-hexafluoro-2-propanol (HFP; Sigma) and then diluted with $\mathrm{dd}_{2} \mathrm{O}$ into $250 \mu \mathrm{M}$ stock solutions. The 20-29 fragment of islet amyloid protein ( $\mathrm{NH}_{2}$-SNNFGAILSS-COOH) was solubilized at $2.5 \mathrm{~mm}$ in $\mathrm{ddH}_{2} \mathrm{O}$. Peptide solutions were used immediately following solubilization (New condition) and or were put into capped vials and placed in a $37^{\circ} \mathrm{C}$ incubator for a $7 \mathrm{~d}$ period (Aged condition).

For the purpose of studying aggregation reversal, some New and Aged $\beta 1-42$ stock solutions were frozen in liquid nitrogen and lyophilized. The dried peptides were resuspended at $250 \mu \mathrm{M}$ in either $\mathrm{ddH}_{2} \mathrm{O}$ or HFP for a $1 \mathrm{hr}$ period, and then lyophilized a second time, and finally resuspended in $\mathrm{ddH}_{2} \mathrm{O}$ at $250 \mu \mathrm{M}$ before use.

Aggregation assessment. The aggregation state of both New and Aged $\beta$ APs was assessed in three ways. First, light microscopy was used to identify the presence of precipitated peptide both in stock solutions and after their addition to tissue culture wells; observations were confirmed by three observers. Second, migration patterns following sodium dodecyl sulfate (SDS)-polyacrylamide gel electrophoresis (PAGE) were examined using the gel and buffer systems described by Laemmli (1970). Samples of $\beta A P$ stock solutions were added to reducing buffer, heated at $100^{\circ} \mathrm{C}$ for $3 \mathrm{~min}$, and electrophoresed on SDS, $15 \%$ polyacrylamide gels at $70 \mathrm{~V}$. Third, the sedimentable portion of $\beta A P$ solutions was quantified using the centrifugation protocol outlined below.

$\beta$ APs were radioiodinated to a specific activity of $\sim 2.6 \times 10^{6} \mathrm{cpm} /$ $\mu \mathrm{g}$, as previously described (Burdick et al., 1992). Solubility constraints required that $\beta 1-47$ and $\beta 1-52$ be radioiodinated in $20 \%$ dimethyl sulfoxide. Radiolabeled stock solutions $(250 \mu \mathrm{M})$ were prepared by combining 70-90 nmol of radioiodinated peptide with 160-180 nmol of unlabeled peptide per $1 \mathrm{ml}$ of $\mathrm{ddH}_{2} \mathrm{O}$. Both $\mathrm{New}$ and Aged radiolabeled stock solutions were diluted to $25 \mu \mathrm{M}$ in Dulbecco's modified Eagle's medium (DMEM; pH 7.3), equilibrated at room temperature for $2 \mathrm{hr}$, and then loaded dropwise $(50 \mu \mathrm{l} /$ tube $)$ into microfuge tubes above 250 $\mu 120 \%$ sucrose pads (pH 7.3). Due to an inability to sediment the $\beta 1-$ 47 and $\beta 1-52$ solutions through sucrose, $10 \mathrm{~mm}$ HEPES (pH 7.3) pads were used instead. Samples were centrifuged (Beckman TL-100 ultra- 
centrifugc, TLA 100.1 rotor) at $100,000 \times g$ for $1 \mathrm{hr}$. Pellet and supernatant fractions were separated and their radioactive counts quantified using a Beckman Gamma 5000 gamma counter. Thin-layer chromatography in a $100 \%$ ethanol solvent system was used to correct supernatant values for free iodine and iodination breakdown products. Percentage sedimentation was calculated as $\left[\Sigma\left(\gamma_{\text {peller }} / \gamma_{\text {corrected supermatant }}+\right.\right.$ $\left.\left.\gamma_{\text {pellet }}\right)\right] / n \times 100$, where $n$ represents number of observations. Due to an inability to iodinate the $\beta 25-35$ and islet amyloid peptides using standard procedures, sedimentation of these peptides was quantified using a Lowry protein determination (Waterborg and Matthews, 1984). To accommodate limitations of this assay, stock solutions were diluted to $25 \mu \mathrm{M}$ in $500 \mu \mathrm{M}$ HEPES (pH 7.3) and centrifuged ( $250 \mu \mathrm{l} /$ tube) through $\mathrm{ddH}_{2} \mathrm{O}$ pads. In comparison tests using iodinated $\beta \mathrm{APs}$, this protein assay yielded results nearly identical to those obtained from gamma counting.

Tissue culture. Short-term neuronal cultures were prepared according to previously described methods with minor modifications (Brewer and Cotman, 1989). Hippocampal tissue from embryonic day 18 SpragueDawley rat pups was dissected and then rinsed in cold $\mathrm{Ca}^{2+} / \mathrm{Mg}^{2+}$-free Hanks' balanced salt solution supplemented with 20 mM HEPES, 4.2 mM sodium bicarbonate, $1 \mathrm{~mm}$ pyruvate, and $3 \mathrm{mg} / \mathrm{ml}$ bovine serum albumin (BSA). Following mechanical dissociation of the tissue with a constricted pipette in cold buffer, two volumes of $10 \%$ fetal bovine serum (FBS) in DMEM were added to the suspension. After the suspension settled for $2 \mathrm{~min}$, the supernatant was collected and centrifuged for 2 min at $200 \times g$. The cell pellet was resuspended in serum-free DMEM (pH 7.3) supplemented with $2.4 \mathrm{mg} / \mathrm{ml} \mathrm{BSA}$ and a modification of Brewer's B16 defined components (with $250 \mathrm{nM}$ vitamin $\mathrm{B} 12$ and without catalase, glutathione, and superoxide dismutase) (Brewer and Cotman, 1989). Cells were plated at a density of 15,000 cells $/ \mathrm{cm}^{2}$ and grown in a humidified incubator at $37^{\circ} \mathrm{C}$ in $5 \% \mathrm{CO}_{2}$. Peptide solutions were diluted from stock samples into defined medium to yield a final concentration of $25 \mu \mathrm{M}$ for $\beta$ APs and $25-250 \mu \mathrm{M}$ for islet amyloid peptide. Peptides were added to cultures either at time of plating or $1 \mathrm{hr}$ later. In control experiments addressing the possibility of substrate-adhesion interference, $\beta 25-35$ and $\beta 1-42$ were added to cultures $24-48 \mathrm{hr}$ after cell plating. To ensure use of a highly neuronal culture system, some cultures were fixed with $2 \%$ glutaraldehyde and immunostained (Vector Elite $\mathrm{ABC}$ kit, Vector diaminobenzidine visualization kit) with antibodies against glial fibrillary acidic protein (1:2500; Dako) and neuronspecific neurofilaments (1:1000; SMI-311, Sternberger Monoclonals, Inc.).

Long-term neuronal cultures utilized hippocampal neurons that were prepared as described above and plated onto purified, secondary astrocyte cultures. Astrocyte cultures were prepared using a modification of the McCarthy and de Vellis (1980) method as previously described (Bridges et al., 1991). Briefly, dissected and triturated neocortical tissue from 2-4 d postnatal Sprague-Dawley rat pups was plated in $75 \mathrm{~cm}^{2}$ flasks and maintained in 10\% FBS supplemented DMEM with three medium changes per week. After 7-10 d, astrocytes were purified from cultures by overnight shaking $(280 \mathrm{rpm})$ followed by trypsinization of remaining cells. Harvested astrocytes were plated $\left(2.5 \times 10^{4} \mathrm{cells} / \mathrm{cm}^{2}\right)$ onto polylysine-coated $16 \mathrm{~mm}$ culture wells and grown to confluency (3-5 d). Neurons were plated $\left(1 \times 10^{5} \mathrm{cells} / \mathrm{cm}^{2}\right)$ onto the astrocyte monolayer and maintained in DMEM supplemented with 10\% FBS. Three days after plating neurons, cultures were given fresh medium and exposed to $10 \mu \mathrm{M}$ cytosine arabinoside (Sigma) for $3 \mathrm{~d}$ to halt glial division. The cultures were then shifted into serum-free DMEM supplemented with N2 components (Bottenstein and Sato, 1979), and 40\% of the medium was subsequently replaced twice per week. Twelve days after plating, neurons were treated with $25 \mu \mathrm{M} \beta 25-35$ initially solubilized to $2.5 \mathrm{~mm}$ in either $\mathrm{ddH}_{2} \mathrm{O}$ or $35 \%$ acetonitrile, $0.1 \%$ TFA. For some experiments, secondary astrocyte cultures were treated as described above except that they were not plated with neurons.

Viability assessment and statistics. Cell viability of short-term cultures was assessed according to morphological characteristics as previously described (Pike et al., 1991b). Cultures were photographed (3 fields/well in a constant pattern) under phase-contrast microscopy $(37.5 \times$; Olympus IMT-2 inverted microscope) $24 \mathrm{hr}$ after plating. Projections of photo negatives onto a $29 \times 31 \mathrm{~cm}$ screen were used to quantify cell survival on the basis of morphological criteria: smooth, round, and vacuole-free phase-bright cells were scored as alive. Control wells always had scored survival levels in excess of 150 cells/well. Each condition was represented in four wells per experiment and repeated at least three times in separate experiments using different peptide stock solutions. Since the number of surviving untreated cells varies across preparations, statistical comparisons were made using raw data in a nested analysis of variance (ANOVA) design with preparations as the nested factor. Survival data is represented graphically as percentage of cell loss in each condition relative to untreated controls using the following formula: $\%$ cell loss $=-100[\Sigma$ (condition survival/control survival) $/ n]+100$, where $n$ represents the number of observations.

Determination of cell viability in long-term neuronal cultures was based on the exclusion of trypan blue dye. Cultures were exposed to $0.2 \%$ trypan blue (GIBCO) for $15 \mathrm{~min}$ and then rinsed with maintenance medium. Stained cultures were photographed $(50 \times)$ as described above. The number of both trypan-positive and trypan-negative cells was counted from projected negatives; cell counts always exceeded 150 cells/ well. Conditions were represented in at least three wells per experiment and repcated in at least three separate experiments. In order to analyze the combined data from all experiments, raw data was converted to $z$-scores and analyzed by one-way ANOVA with Scheffé $F$ test post hoc analysis. Cell count data is represented graphically as the percent of control values.

Cell viability of $\beta 25-35$ treated secondary astrocyte cultures was determined by lactate dehydrogenase assay using the method described by Koh and Choi (1987).

\section{Results}

\section{$\beta A P$ aggregation}

Based on our previous findings with the $\beta 1-28$ and $\beta 1-42$ peptides, we expanded our investigation of differential $\beta$ AP assembly and its relationship with neurotoxicity using several synthetic $\beta$ APs (Fig. 1). The peptide $\beta 1-15$ represents the fragment that may result from the predicted normal cleavage of APP near residue 16 (Esch et al., 1990). The truncatcd $\beta 25-35$ fragment includes extracellular and transmembrane residues and has been reported to represent an active region of $\beta$-amyloid that shows some homology with tachykinin neuropeptides (Yankner et al., 1990). The remaining series of peptides beginning with $\beta 1-28$ are progressively longer at their $\mathrm{C}$-termini and thus include increasingly longer portions of the transmembrane domain: $\beta 1-$ $30, \beta 1-33, \beta 1-36, \beta 1-39, \beta 1-42, \beta 1-47, \beta 1-52$.

Upon light microscopic examination of freshly prepared (New) $\beta$ AP stock solutions, most peptides appeared completely soluble, lacking any visible indication of precipitated aggregates (Table 1). In contrast, the New $\beta 25-35, \beta 1-47$, and $\beta 1-52$ stock solutions exhibited both fine particulate and larger sheet-like precipitates consistent in appearance with our previous observations (Pike et al., 1991a,b). Dilution of $\beta$ APs into tissue culture medium creates conditions less suitable for aggregation, since the result is a 10 -fold decrease in molar concentration and a pH increase from $\sim 5$ to 7.3 (Burdick et al., 1992). Despite these changes, microscopic examination of New $\beta$ APs added to culture wells mirrored observations of stock solutions, with aggregates still visible in the $\beta 25-35, \beta 1-47$, and $\beta 1-52$ conditions (Table 1).

Following a $7 \mathrm{~d}$ incubation of the stock solutions at $37^{\circ} \mathrm{C}$ (Aged), aggregates were visible under the light microscope in all of the stock solutions with the exception of $\beta 1-15$. Following dilution into DMEM, however, stable aggregate structures were visible only for $\beta 25-35, \beta 1-36, \beta 1-39, \beta 1-42, \beta 1-47, \beta 1-52$, and, to a lesser extent, $\beta 1-33$ (Table 1).

The light microscopic observations agree well with SDS-PAGE analysis of the New $\beta$ APs (Fig. $2 A$ ). The $\beta 1-15, \beta 1-28, \beta 1-30$, $\beta 1-33, \beta 1-36$, and $\beta 1-39$ peptides show single, apparently monomeric bands. The broad and higher than expected molecular weights of some monomeric bands likely represents an artifact of reducing gels, as previously reported (Burdick et al., 1992). 
Table 1. Visualization of precipitated $\beta A P$ aggregates under light microscopy

\begin{tabular}{|c|c|c|c|c|}
\hline \multirow[b]{2}{*}{$\beta \mathrm{AP}$} & \multicolumn{2}{|l|}{ New } & \multicolumn{2}{|l|}{ Aged } \\
\hline & $\begin{array}{l}\text { Stock } \\
\text { solution }\end{array}$ & DMEM & $\begin{array}{l}\text { Stock } \\
\text { solution }\end{array}$ & DMEM \\
\hline$\beta 1-15$ & - & - & - & - \\
\hline$\beta 1-28$ & - & - & + & - \\
\hline$\beta 1-30$ & - & - & + & - \\
\hline$\beta 1-33$ & - & - & + & $+1-$ \\
\hline$\beta 25-35$ & + & + & + & + \\
\hline$\beta 1-36$ & - & - & + & + \\
\hline$\beta 1-39$ & - & - & + & + \\
\hline$\beta 1-42$ & - & - & + & + \\
\hline$\beta 1-47$ & + & + & + & + \\
\hline$\beta 1-52$ & + & + & + & + \\
\hline
\end{tabular}

$\beta \mathrm{AP}$ fragments were examined under light microscopy both in stock solutions $(250 \mu \mathrm{M}, \mathrm{pH} \sim 5)$ and following addition to culture medium $(25 \mu \mathrm{M}, \mathrm{pH} 7.3)$ for the presence of particulate precipitate and sheet-like structures characteristic of aggregation. Observations were made after both initial peptide solubilization (New) and $7-d$ incubation of stock solutions (Aged). - , no visible aggregates; + , visible aggregates; +/-, limited, inconsistent visualization of aggregates.

The $\beta 1-42$ peptide exhibits not only a predominant monomeric band $(\sim 4.5 \mathrm{kDa})$ but also an apparent tetrameric band $(\sim 18$ $\mathrm{kDa})$ suggesting an early aggregated component. In contrast, $\beta 25-35$ will not enter the gel and is recognized only as a strongly insoluble band at the top of the stacking gel. The $\beta 1-47$ and $\beta 1-52$ peptides also exhibit high-molecular-weight bands that are inconsistent with denatured monomers. In agreement with previous reports (Hilbich et al., 1991; Burdick et al., 1992), we interpret bands of much higher than expected molecular weight that are located at the stacking/separating gel interface and or at the top of the stacking gel as insoluble forms of aggregated $\beta$-amyloid. A similar electrophoretic pattern has also been described for insoluble $\beta$-amyloid purified from AD brain tissue (Masters et al., 1985a; Selkoe et al., 1986).

Electrophoretic patterns of Aged $\beta 1-15, \beta 1-28, \beta 1-30, \beta 1-$ 33 , and $\beta 1-36$ suggest monomeric peptides under reducing conditions (Fig. $2 B$ ). In three out of six experiments, Aged $\beta 1-39$ exhibited a high-molecular-weight band characteristic of aggregated peptides. This variability may reflect a transition region in $\beta$ AP after which the aggregated forms of full-length $\beta$ APs become the predominant species. Aged $\beta 1-42$ consistently exhibits several bands, suggesting multiple stable aggregate intermediates. Following aging, the $\beta 1-47$ and $\beta 1-52$ peptides show increased aggregation evidenced by predominant stacking gel bands, whereas $\beta 25-35$ remains a single, insoluble band.

Since neither microscopic examination nor SDS-PAGE yields quantitative aggregation data and because the peptide conditions in electrophoresis do not parallel those in tissue culture, we employed a centrifugation assay to assess $\beta \mathrm{AP}$ aggregation further under more suitable conditions. Radioiodinated $\beta \mathrm{AP}$ stock solutions were diluted to $25 \mu \mathrm{M}$, equilibrated to $\mathrm{pH} 7.3$, and then centrifuged at $100,000 \times g$ for $1 \mathrm{hr}$. Quantitation of peptide amounts in both the pellets and supernatants permitted calculation of the percentage of sedimentable material. As shown in Figure $3, \beta 25-35, \beta 1-47$, and $\beta 1-52$ are the only New $\beta$ APs that have a statistically significant level of sedimentation. Following a $7 \mathrm{~d}$ aging period, $\beta 1-36, \beta 1-39$, and $\beta 1-42$ also demonstrate aggregation with significant levels of sedimentation.
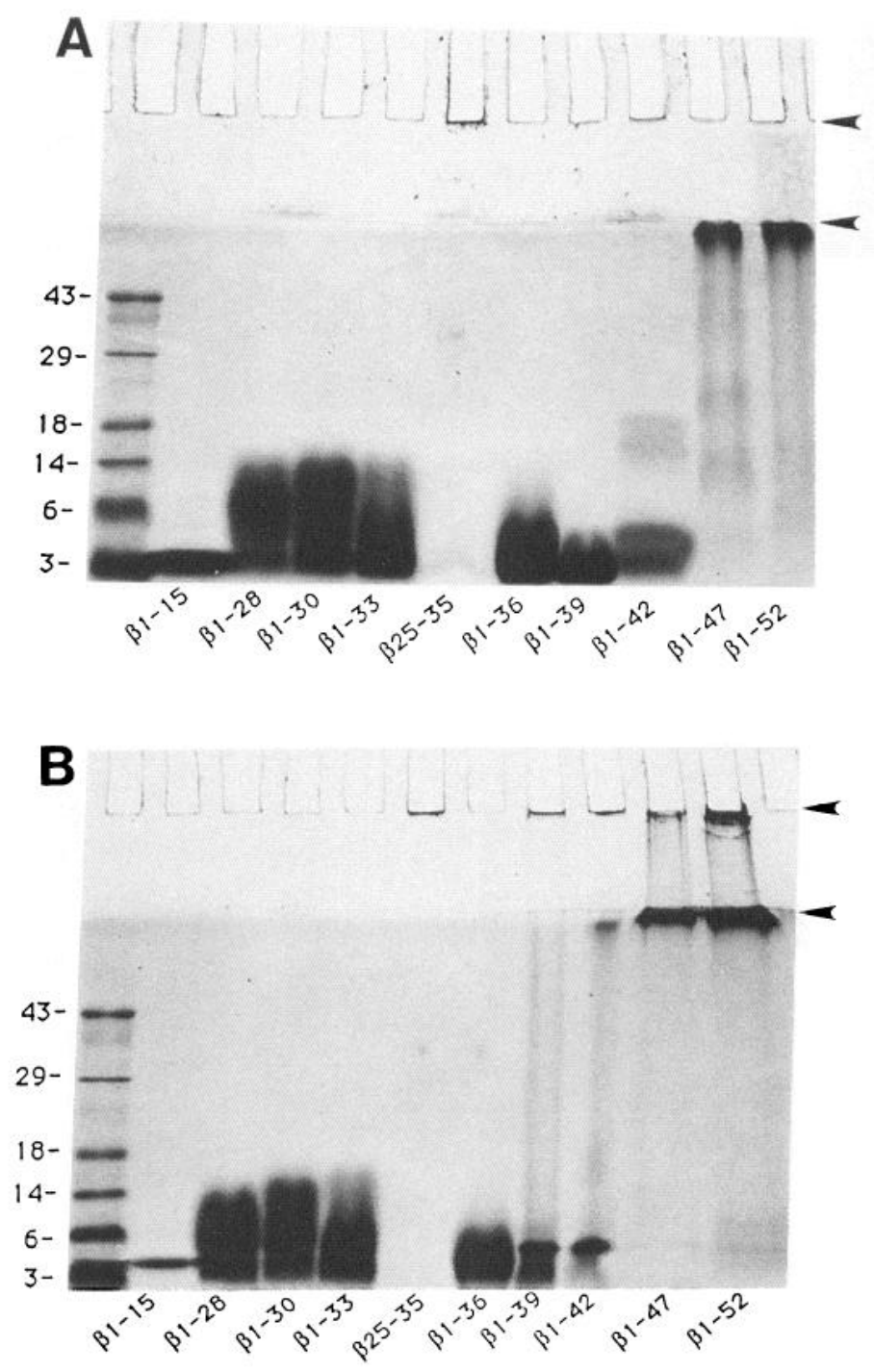

Figure 2. SDS-PAGE analyses indicate that several New and Aged $\beta$ APs form aggregates resistant to denaturation. $A$, Among the New $\beta$ APs, only $\beta 25-35, \beta 1-47$, and $\beta 1-52$ exhibit high-molecular-weight bands (arrowheads) characteristic of aggregation. $B$, Aggregation bands are apparent in several $\beta$ APs following incubation of peptide solutions: Aged $\beta 25-35, \beta 1-39, \beta-42, \beta 1-47$, and $\beta 1-52$. Protein standards (GIB$\mathrm{CO}-$ Bethesda Research Laboratories, low range) with indicated molecular masses (in kilodaltons) were run in the far left lane. Twelve micrograms of $\beta \mathrm{AP} /$ lane were run in $15 \%$ polyacrylamide gels, followed by staining with Coomassie brilliant blue.

\section{$\beta A P$ neurotoxicity in short-term cultures}

Since our previous studies had documented neuronal loss only in the presence of aggregated $\beta$ APs, we hypothesized that in vitro neurodegeneration should result specifically following treatment with any $\beta$ APs, New or Aged, that demonstrate significant levels of aggregation. In order to test this prediction, we treated shortterm hippocampal cultures with both New and Aged $\beta$ APs at the previously established effective concentration of $25 \mu \mathrm{M}$ (Pike et al., 1991b) and determined cell viability $24 \mathrm{hr}$ later. Immunostaining of selected cultures confirmed that neurons comprised approximately $95 \%$ of the viable cells in untreated wells, a finding consistent with previous reports (Banker and Cowan, 1977; Barbin et al., 1984). Use of this highly neuronal, shortterm culture system simplifies interpretation of toxicity data 
Figure 3. Sedimentation assays measure $\beta \mathrm{AP}$ aggregation under culture-like conditions. Aggregation of New (hatched bars) and Aged (solid bars) BAPs was assessed by quantifying the percentage of peptide that sedimented following 1 hr of ultracentrifugation at $100,000 \times$ $g$. Bars represent mean percentage sedimentation values $( \pm$ SEM) of three or four observations. Statistical analyses were performed using one-way ANOVA $[F(19,53)=60.39, p=0.0001]$ and the Scheffe $F$ test for post hoc betweengroup comparisons. ${ }^{*}, p<0.05$ relative to the nonaggregating peptide New $\beta 1-$ 15.

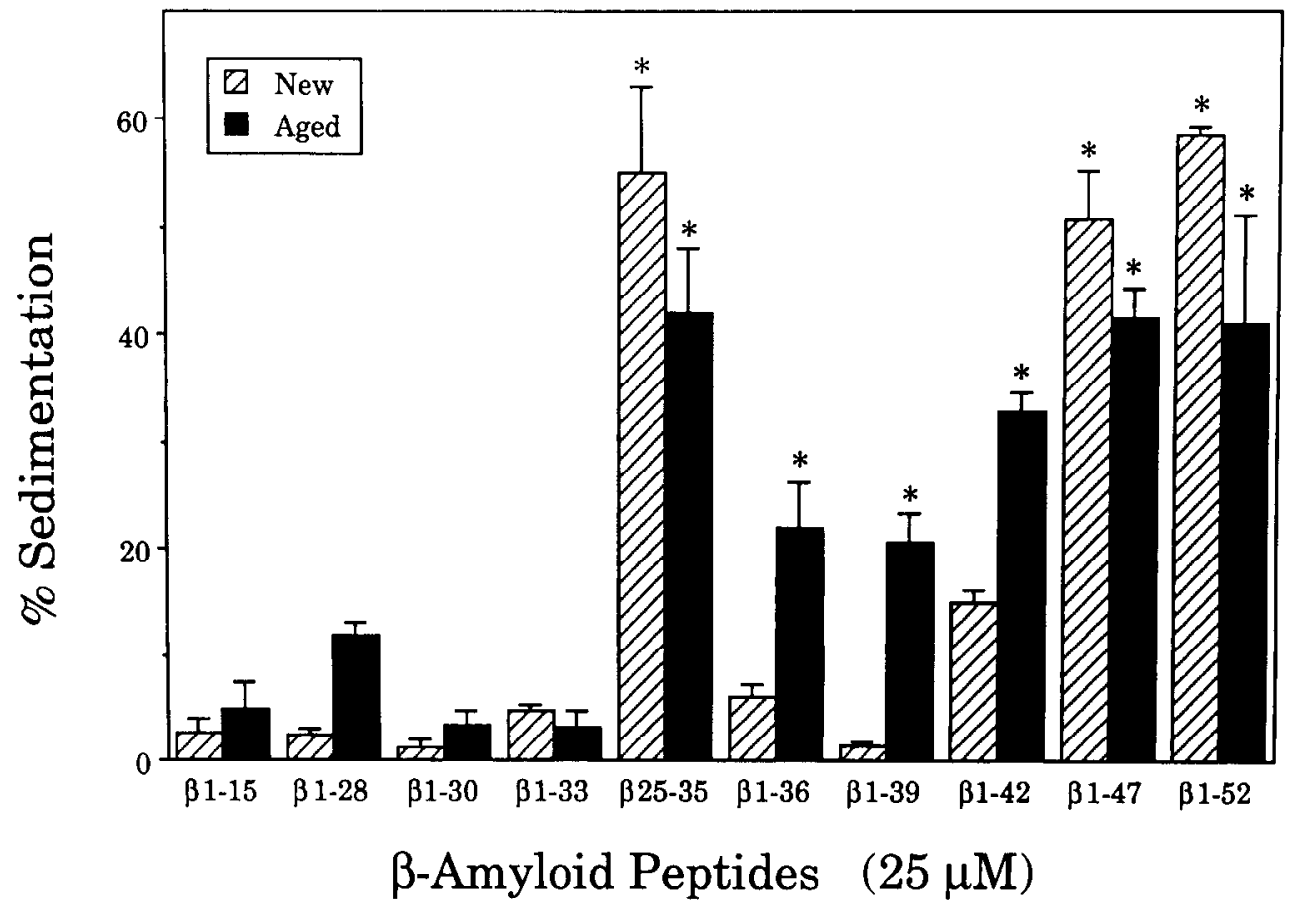

since the potential contributions of both glia-neuron interactions and glutamate receptor activation are minimized.

Although $\beta$ APs were not observed to interfere with cell-substratum adhesion, they were typically added to cultures $1 \mathrm{hr}$ after plating to avoid this potential pitfall. Microscopic examination of $\beta \mathrm{AP}$-treatcd culture wclls revcalcd no floating cells or other visible indications of cell detachment. To address this issue further, selected aggregated $\beta$ APs were added to cultures $24 \mathrm{hr}$ and $48 \mathrm{hr}$ after plating. This delayed treatment did not affect the magnitude of $\beta$ AP-induced toxicity (data not shown).

Hippocampal cultures responded to most New $\beta$ APs with survival levels comparable to untreated controls (Fig. 4). However, cultures treated with three of the New $\beta$ APs demonstrated significant reductions in survival: $\beta 25-35$ showed $64.2 \% \pm 2.7 \%$ cell loss in comparison to controls; $\beta 1-47,64.0 \% \pm 4.7 \%$; and $\beta 1-52,71.8 \% \pm 3.7 \%$. Since $\beta 1-47$ and $\beta 1-52$ were initially solubilized in HFP, the appropriate HFP dilution $(\sim 1: 400)$ was added directly to cultures but was not found to be toxic. Because some New $\beta$ APs displayed both significant aggregation and toxicity, their toxicity could not be definitively related to aggregation without demonstration that nonaggregated forms of the $\beta$ APs also lack toxicity. Thus, we solubilized separate $\beta 25-35$

Figure 4. Significant cell loss is observed following treatment with aggregated $\beta$ APs. The effect of New (hatched bars) and Aged (solid bars) $\beta$ APs on cell survival was determined $24 \mathrm{hr}$ after their addition to short-term neuronal cultures. Bars represent mean percentage cell loss ( \pm SEM). Significant cell loss was observed for New $\beta 25-35, \beta 1-47$, ad $\beta 1-52$ and Aged $\beta 25-35, \beta 1-36, \beta 1-$ $39, \beta 1-42, \beta 1-47$, and $\beta 1-52$. Statistical analyses were conducted for each condition using raw data and nested ANOVAs. ${ }^{*}, p<0.05$ relative to untreated control groups.

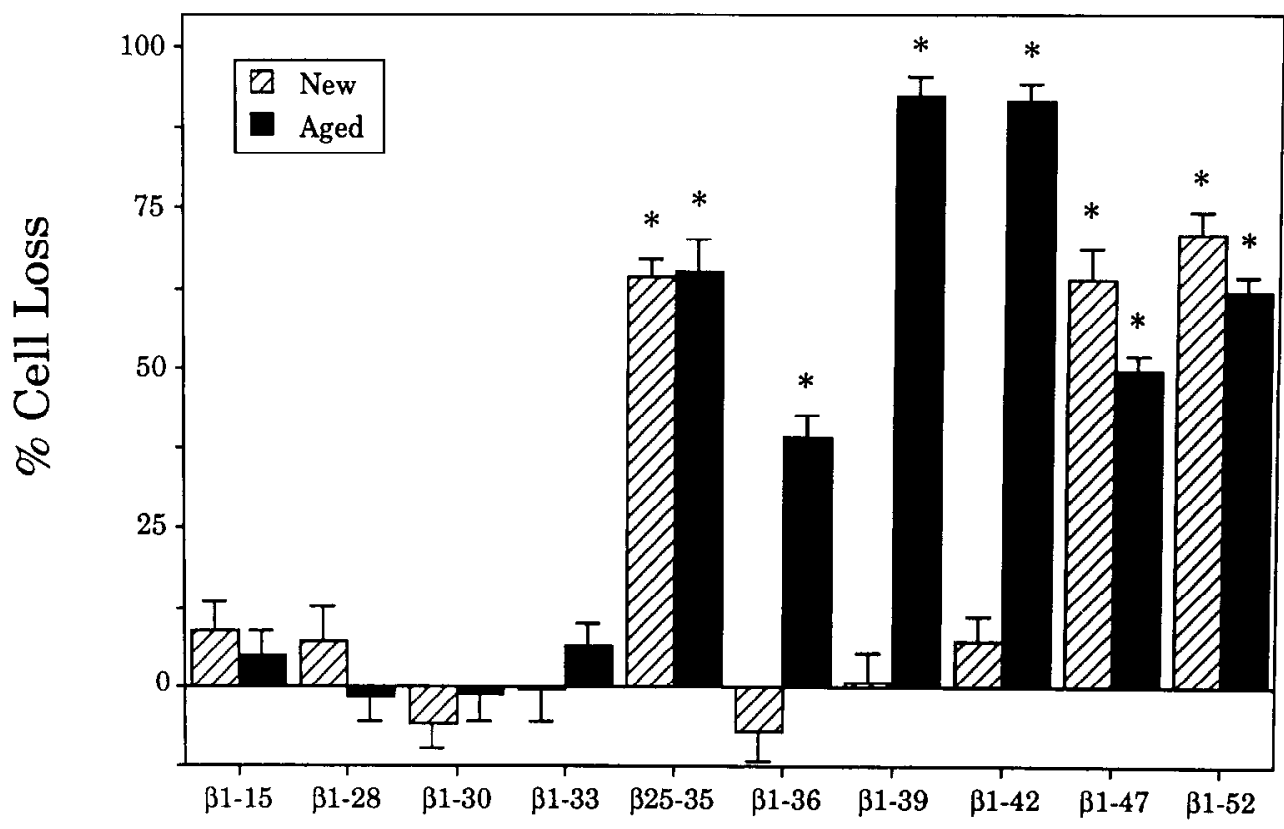

$\beta$-Amyloid Peptides $(25 \mu \mathrm{M})$ 

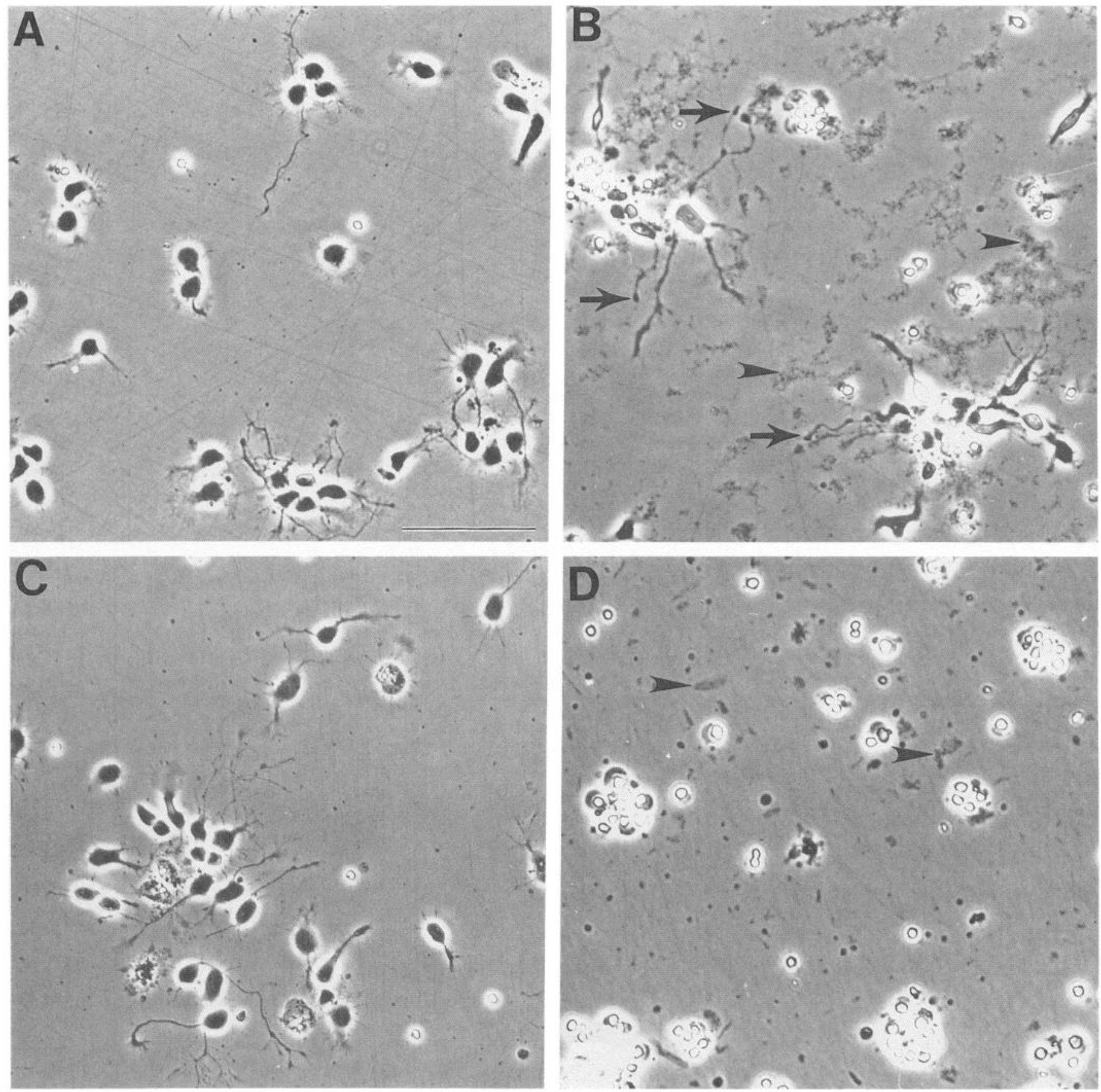

Figure 5. Aggregated $\beta$ APs cause degenerative changes in cultured neurons. Treatment of short-term hippocampal cultures with aggregated $\beta$ APs $(25 \mu \mathrm{M})$ results in distinct morphological changes within $24 \mathrm{hr}$. $A$, Untreated control cells appear healthy and extend short processes. $B$, In the New $\beta 25-35$ condition, most cells exhibit either swollen, dystrophic neurites (arrows) or complete degeneration (cellular collapse); many large aggregate precipitates are also visible (arrowheads). $C$, In wells with New $\beta 1-39$, no aggregates are visible and, as in the control condition, cells show no apparent degeneration. D, However, in the Aged $\beta 1-39$ condition both aggregates (arrowheads) and severe cell loss are observed. Scale bar, 100 $\mu \mathrm{m}$.

samples in $35 \%$ acetonitrile, $0.1 \%$ TFA rather than in $\mathrm{ddH}_{2} \mathrm{O}$ alone, a procedure previously demonstrated to yield soluble $\beta$ APs (Yankner et al., 1990). We found that New $\beta 25-35$ (35\% acetonitrile, $0.1 \%$ TFA) was absent of significant aggregation $[7.8 \% \pm 2.8 \%$ sedimentation; in comparison to New $\beta 1-15$, $F(1,7)=2.9, p=0.14]$ and did not induce toxicity $[105.3 \% \pm$ $5.0 \%$ cell survival in comparison to vehicle-treated controls; $F(1,20)=0.71, p=0.41]$.
Hippocampal cultures were also treated with Aged $\beta$ APs. Following the peptide aging period, $\beta 1-15, \beta 1-28, \beta 1-30$, and $\beta 1-$ 33 continued to exert no significant effect on the survival of hippocampal neurons whereas $\beta 25-35, \beta 1-47$, and $\beta 1-52$ still exhibited significant toxic effects (Fig. 4). Unlike their relatively benign influences in the newly solubilized condition, Aged $\beta 1-$ $36, \beta 1-39$, and $\beta 1-42$ caused widespread and, in some instances, nearly total neuronal degeneration. 

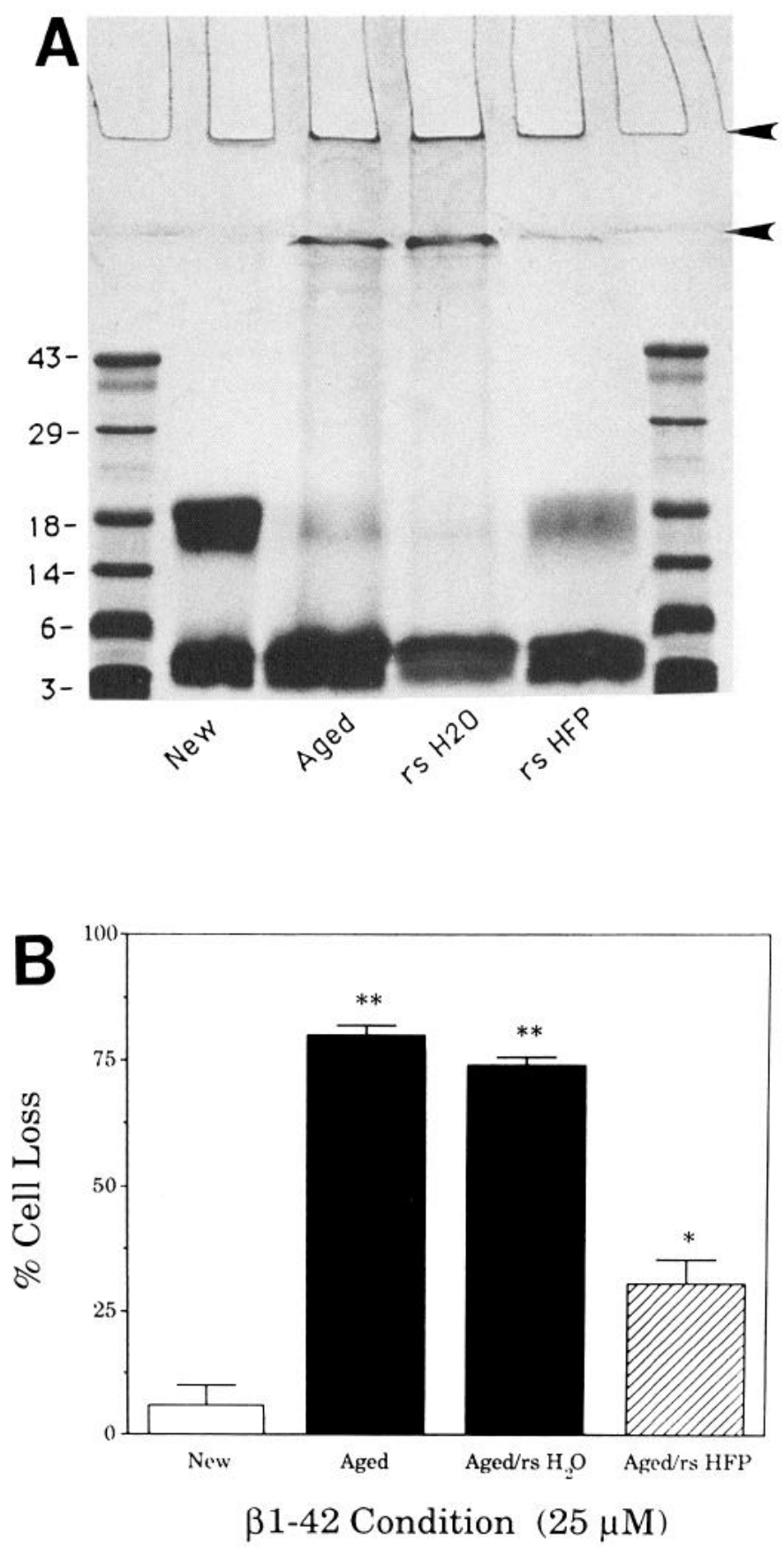

Figure 6. Both the aggregation and neurotoxicity of Aged $\beta 1-42$ are partially reversed by HFP-resolubilization treatment. $A$, Analysis by SDS-PAGE shows strong aggregation bands (arrowheads) in the lanes corresponding to Aged $\beta 1-42$ (Aged) and Aged $\beta 1-42$ resolubilized in $\mathrm{ddH}_{2} \mathrm{O}(r s \mathrm{H} 2 \mathrm{O}$ ). Aged $\beta 1-42$ resolubilized in HFP ( $r S H F P$ ) exhibits less intense aggregation bands and a stronger tetramer $(\sim 18 \mathrm{kDa})$ band, similar to the profile of newly solubilized $\beta 1-42(\mathrm{New})$. Molecular masses (in kilodaltons) of protein standards are indicated. $B$, Both Aged $\beta 1-$ 42 and Aged $\beta 1-42$ resolubilized in $\mathrm{ddH}_{2} \mathrm{O}$ cause severe cell loss in short-term neuronal cultures. Significantly less cell loss is caused by Aged $\beta 1-42$ resolubilized in HFP. ${ }^{*}, p<0.05$ relative to untreated controls; ${ }^{* *}, p<0.05$ relative to both untreated controls and Aged $\beta 1-$ 42/rs HFP.

The $\beta \mathrm{AP}$-induced degeneration resulted in obvious changes in neuronal morphology, including swollen and beaded neurites, vacuolar inclusions, and cellular collapse (Fig. 5). These degenerative events exhibited a fairly rapid onset, with observable morphological changes typically beginning within $4-8 \mathrm{hr}$ of $\beta \mathrm{AP}$ treatment. We have recently reported that these morphological changes are an initial and definitive stage in the process of $\beta$ APinduced degeneration in vitro (Copani et al., 1992; A. Copani, D. T. Loo, C. J. Pike, A. J. Walencewicz, and C. W. Cotman, unpublished observations). The morphological changes are succeeded by a significant decrease in metabolic activity [as assayed by 3-(4,5-dimethylthiazol-2-yl)-2,5-diphenyl tetrazolium bromide (MTT)], condensation of nuclear chromatin, pronounced fragmentation of DNA, membrane blebbing, and eventually cell lysis (as determined by lactate dehydrogenase release and positive trypan blue staining).

\section{Aggregation reversal}

A corollary of our hypothesis of aggregation-related toxicity is that the reversal of peptide aggregation should be accompanied by a corresponding attenuation of toxicity. To investigate this possibility, we attempted to reverse the aggregation state of Aged $\beta 1-42$ with the $\alpha$-helix-promoting solvent HFP, since previous studies have demonstrated that $\beta$ APs insoluble in aqueous media show increased solubility in this solvent (Halverson et al., 1990; Hilbich et al., 1991; Burdick et al., 1992). Sister samples of Aged $\beta 1-42$ were lyophilized and then temporarily resuspended at $250 \mu \mathrm{M}$ : one in $\mathrm{ddH}_{2} \mathrm{O}\left(\beta 1-42 / \mathrm{H}_{2} \mathrm{O}\right)$, the other in HFP $(\beta 1-42 /$ HFP). The samples were lyophilized again and resuspended in $\mathrm{ddH}_{2} \mathrm{O}$ at $250 \mu \mathrm{M}$. Aliquots of these two final $\beta 1-42$ solutions were compared in SDS-PAGE with an aliquot of the original, untreated Aged $\beta 1-42$ and a New $\beta 1-42$ sample (Fig. $6 A$ ). Although the New $\beta 1-42$ lane shows a strong $\sim 18$ $\mathrm{kDa}$ band in addition to its monomeric band, it does not exhibit the characteristic aggregation bands visible in the Aged $\beta 1-42$ lane. Aggregation bands are also apparent for Aged $\beta 1-42 / \mathrm{H}_{2} \mathrm{O}$, but are substantially decreased in Aged $\beta 1-42 / \mathrm{HFP}$, suggesting a partial reversal of aggregation as a result of HFP exposure.

Samples from these four $\beta 1-42$ solutions were also assayed for toxicity using the short-term hippocampal culture paradigm. Consistent with our previous data, Aged $\beta 1-42$ but not New $\beta 1-42$ caused significant neuronal degeneration. Aged $\beta 1-42 /$ $\mathrm{H}_{2} \mathrm{O}(74.0 \% \pm 1.7 \%$ cell loss) exacted levels of cell damage nearly identical to the untreated Aged $\beta 1-42(80.1 \% \pm 1.7 \%$ cell loss). Cultures exposed to the Aged $\beta 1-42 / \mathrm{HFP}(30.6 \% \pm$ $4.7 \%$ cell loss) exhibited significantly less degeneration than both Aged $\beta 1-42 / \mathrm{H}_{2} \mathrm{O}$ and untreated Aged $\beta 1-42$, but still significantly more than New $\beta 1-42$ and the untreated controls (Fig. $6 B$ ). Because the toxicity caused by Aged $\beta 1-42 /$ HFP could have been due to incomplete aggregation reversal and/or an effect of HFP, we then treated cultures with New $\beta 1-42$ samples that had been subjected to the HFP resolubilization procedure. New $\beta 1-42 / \mathrm{HFP}(30.1 \% \pm 3.0 \%$ cell loss) caused a response commensurate with that of Aged $\beta 1-42 /$ HFP. Since direct addition of HFP to culture medium ( 1:400 final dilution) did not affect cell survival, these data suggest that the neurodegeneration observed in $\beta 1-42 /$ HFP conditions may be related to an indirect effect of HFP (e.g., HFP-induced conformational changes).

\section{Islet amyloid polypeptide}

Islet amyloid polypeptide (IAP) is a 37 amino acid protein that forms amyloid deposits in the pancreases of type 2 diabetes patients (Cooper et al., 1987; Westermark et al., 1987). Previous work has demonstrated that an internal sequence of IAP (residues 20-29) is likely responsible for IAP amyloidogenicity since a synthetic peptide homologous to this region forms twisted 
$\beta$-pleated sheet fibrils in vitro (Glenner et al., 1988) and exhibits positive Congo red staining (Glenner et al., 1988; Westermark et al., 1990). In order to address the possibility that the neurotoxicity associated with aggregated $\beta$ APs may result from a nonspecific neuronal interaction with aggregated, amyloidogenic proteins in general rather than a more specific response to aggregated $\beta \mathrm{AP}$, we examined the aggregation and biological activities of the 20-29 region of IAP (IAP20-29).

Both New and Aged stock solutions of synthetic IAP20-29 exhibited particulate matter that was similar in appearance to aggregates of $\beta$ AP. These IAP aggregates stained positively with thioflavin-S (data not shown) and remained stable following addition to culture medium. Upon ultracentrifugation, IAP2029 showed sedimentation values $(18.4 \% \pm 3.2 \%$ for newly solubilized, $25 \mu \mathrm{M}$ solution) similar to some aggregating $\beta$ APs. In contrast to aggregating $\beta$ APs, addition of $25 \mu \mathrm{M}$ IAP20-29 to short-term hippocampal cultures did not induce degenerative morphological changes (Fig. 7A). In fact, IAP20-29 did not significantly affect neuronal survival at any of the tested concentrations, which ranged from 25 to $250 \mu \mathrm{M}$ (Fig. $7 B$ ).

\section{$\beta A P$ neurotoxicity in long-term cultures}

Although short-term cultures are an advantageous paradigm for this study, it is important to demonstrate that findings derived from them can be extrapolated to fully developed long-term cultures containing both neuronal and glial elements, a paradigm that more closely parallels in vivo conditions. Thus, we examined the effects of $25 \mu \mathrm{M} \beta 25-35$, the proposed active fragment of $\beta$-amyloid, in both its soluble and aggregated forms on longterm cultures consisting of hippocampal neurons plated on top of a confluent astrocyte monolayer. As described above in shortterm culture experiments, soluble $\beta 25-35$ was attained by initial solubilization in $35 \%$ acetonitrile, $0.1 \%$ TFA whereas aggregated $\beta 25-35$ resulted from solubilization in $\mathrm{ddH}_{2} \mathrm{O}$.

Cultures were treated with $\beta 25-35$ after the neurons had been cultured for $12 \mathrm{~d}$; untreated neurons were observed to retain viability for at least $21 \mathrm{~d}$ in this culture system. Similar to results with short-term cultures, neurons in long-term cultures treated with soluble $\beta 25-35$ appeared morphologically normal after 24 $\mathrm{hr}$ whereas those exposed to aggregated $\beta 25-35$ exhibited morphological indications of degeneration, including somal shrinkage and neuritic regression. Cell viability was assessed by trypan blue exclusion rather than morphological criteria due to the difficult nature of quantifying morphological degeneration by phase-contrast microscopy in high-density, mature cultures. Since cell lysis is a late event in $\beta$ AP-induced degeneration (Copani et al., 1992; Copani, Loo, Pike, Walencewicz, and Cotman, unpublished observations), viability determinations were made $72 \mathrm{hr}$ after $\beta 25-35$ treatment. Similar to control wells, those treated with soluble $\beta 25-35$ exhibited very few trypan-positive cells, indicating a general absence of cell lysis. In contrast, neurons exposed to aggregated $\beta 25-35$ showed a significant level of degeneration with approximately $30 \%$ staining trypan positive (Fig. 8). Because the total number of cells (sum of trypanpositive and trypan-negative cells) did not significantly vary across conditions, cell detachment can be excluded as the primary contributor to the observed degeneration.

The observed degeneration was limited to neurons since sister astrocyte cultures containing no neurons did not show significant degeneration following $72 \mathrm{hr}$ exposure to $25 \mu \mathrm{M}$ concentrations of either soluble or aggregated $\beta 25-35$. Although $\beta$ AP treatment induced reactive morphology in astrocytes within $24 \mathrm{hr}$, at 72
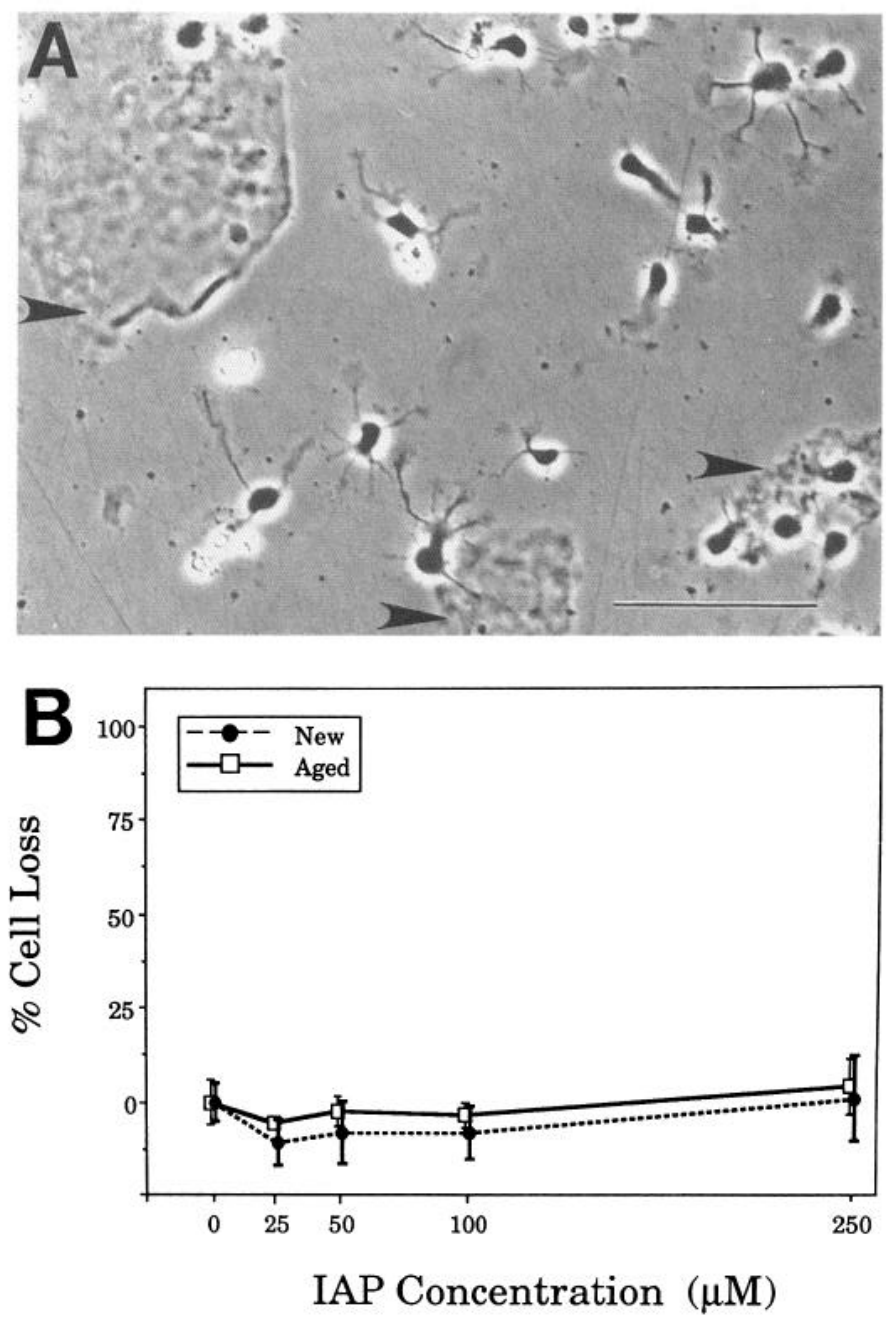

Figure 7. IAP20-29 exhibits aggregation but does not induce toxicity. $A$, After $24 \mathrm{hr}$ in vitro, short-term cultured neurons exposed to $25 \mu \mathrm{M}$ New IAP20-29 do not exhibit any morphological indications of degeneration despite the presence of stable peptide aggregates (arrowheads). $B$, In concentrations from $25-250 \mu \mathrm{M}$, neither New (broken line) nor Aged (solid line) IAP20-29 significantly affected cell survival. New conditions: $F(4,50)=0.37, p=0.83$; Aged conditions: $F(4,57)=1.4, p=$ 0.25 . Scale bar $(A), 100 \mu \mathrm{m}$.

hr $\beta 25-35$ treated cultures did not exhibit significant cell lysis in comparison to control cultures, as determined by lactate dehydrogenase release (one-way ANOVA, $F(3,20)=2.34, p>$ $0.10)$.

A previous study reported that the $\beta$ AP potentiation of an endogenous glutamate insult in long-term cortical cultures was markedly attenuated by addition of MK801, a selective, noncompetitive antagonist for the NMDA class of glutamate receptor (Copani et al., 1991). Other reports suggest that excitotoxic degeneration of long-term hippocampal cultures is effectively prevented by MK801 (Rondouin et al., 1988; Abele et al., 1990). Thus, we investigated the possibility that this glutamate antagonist would protect against $\beta \mathrm{AP}$-induced degeneration in our long-term cultures. Although $3 \mu \mathrm{M}$ MK801 reduced by nearly $50 \%$ the toxicity induced by $1 \mathrm{~mm}$ glutamate over $72 \mathrm{hr}$ (Scheffé $F$ value $=6.24, p<0.01$ ), it did not significantly affect the cell loss caused by exposure to $25 \mu \mathrm{M}$ aggregated $\beta 25-35$ (Scheffé $F$ value $=0.35, p>0.1$ ). 

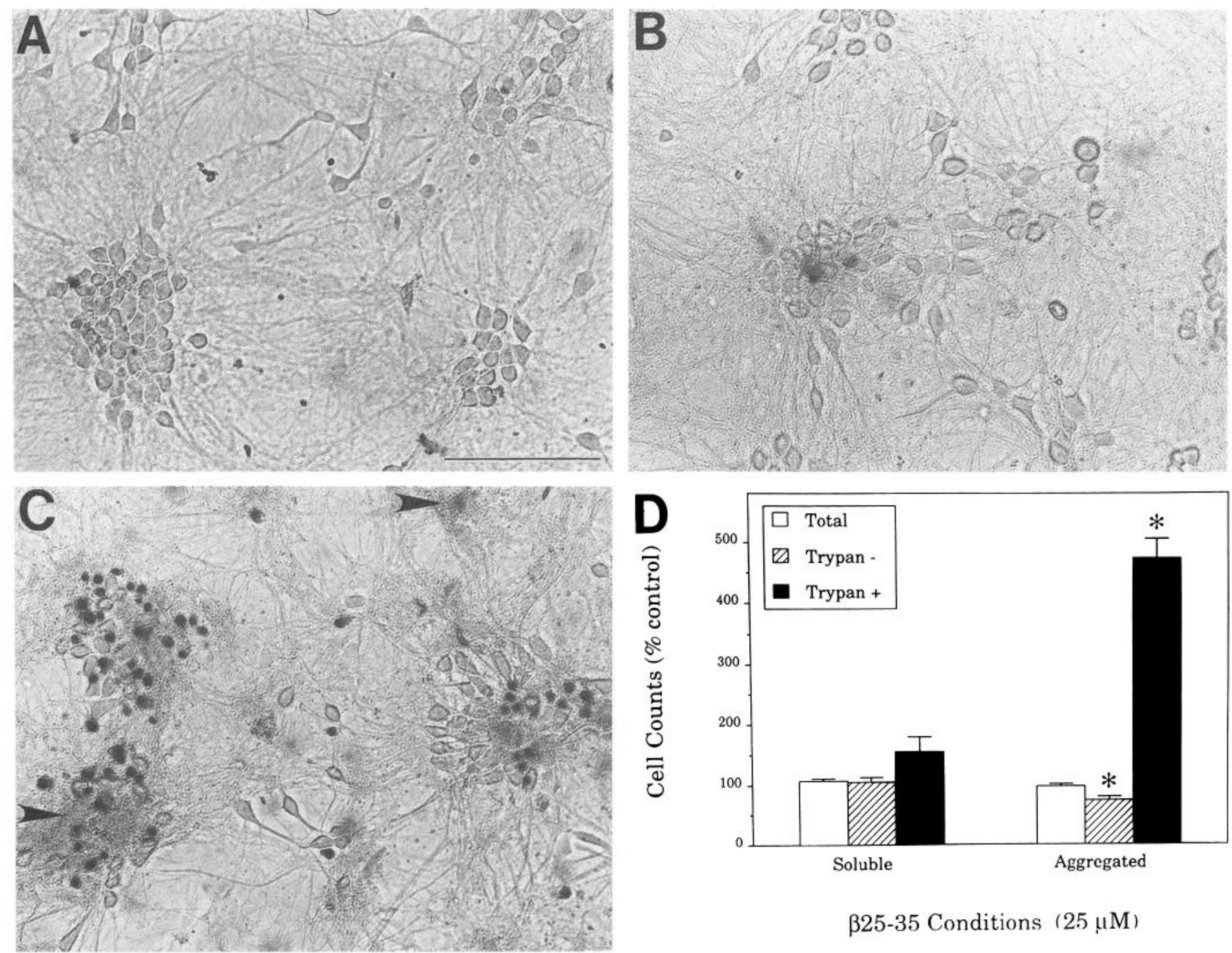

B25-35 Conditions $(25 \mu \mathrm{M})$

Figure 8. Aggregated $\beta \mathrm{AP}$ induces neurodegeneration in long-term cultures. $A$, Untreated long-term cultured neurons exhibit good viability as evidenced by intact neurites and exclusion of trypan blue dye. Cultures are viewed under bright-field microscopy. $B$, Similarly, neurons treated with soluble $25 \mu \mathrm{M} \beta 25-35$ exclude trypan blue. $C$, Conversely, positive trypan staining of neurons treated with $25 \mu \mathrm{M}$ aggregated $\beta 25-35$ indicates extensive cell lysis. Arrowheads indicate $\beta 25-35$ aggregates that show light, nonspecific trypan staining. $D$ Cell counts of trypan-stained cultures demonstrate that all conditions have the same number of cells, but that the aggregated $\beta 25-35$ condition has significantly fewer viable (trypan negative) and significantly more degenerated (trypan-positive) neurons. ${ }^{*}, p \leq 0.01$ in comparison to control condition. Scale bar $(A), 100 \mu$ m.

\section{Discussion}

In this article, we have evaluated the hypothesis that the state of $\beta$-amyloid aggregation is related to its neurotoxic properties. The data support our prediction that those $\beta$ APs exhibiting stable aggregates are neurotoxic. The state of $\beta \mathrm{AP}$ aggregation, assayed by sedimentation studies to provide quantitative data under conditions parallel to those in culture, predicts the documented toxicity. Significant aggregation was found for New $\beta 25-35, \beta 1-47$, and $\beta 1-52$ and Aged $\beta 25-35, \beta 1-36, \beta 1-39, \beta 1-$ $42, \beta 1-47$, and $\beta 1-52$. Similarly, significant toxicity was limited to these aggregating peptides. Further, we demonstrate that the reduction of $\beta \mathrm{AP}$ aggregation by specific solvents is accompanied by corresponding reductions in toxicity.

$\beta$ AP aggregation results from the tendency of $\beta$-amyloid to adopt solution conformations that promote its self-association into dimer, tetramer, and multimer peptide assemblies. These assemblies exhibit $\beta$-sheet conformation (Kirschner et al., 1987; Halverson et al., 1990; Barrow and Zagorski, 1991), high in- solubility (Halverson et al., 1990; Hilbich et al., 1991; Burdick et al., 1992), and positive staining with Congo red (Hilbich et al., 1991; Burdick et al., 1992) and thioflavin (Burdick et al., 1992), similar to $\beta$-amyloid isolated from the senile plaques of AD brains. Deposition of $\beta$-amyloid in $\mathrm{AD}$, and thus senile plaque formation, likely depends upon the self-assembly of $\beta$-amyloid protein, which presumably results from an abnormal proteolysis of APP. On the basis of our data, only $\beta$ APs containing the hydrophobic $\beta 29-35$ sequence are predicted to form stable assemblies that are resistant to unfavorable conditions (e.g., low $\beta$ AP concentration, solution $\mathrm{pH}>7$ ). In agreement with this prediction, aqueous solutions of $\beta 29-42$ are reported to be entirely $\beta$-sheet in structure whereas $\beta 1-28$ solutions are random coil (Barrow and Zagorski, 1991). These data suggest that a variety of hydrophobic $\beta$ APs could be deposited in the $\mathrm{AD}$ brain, a possibility consistent with reports of ragged $\mathrm{N}$-termini in $\beta$ APs isolated from senile plaques (Masters et al., $1985 a, b)$. Together, our aggregation data more clearly define the sequence requirements for stable $\beta \mathrm{AP}$ aggregates and serve as 
a basis for predictions concerning assembly-related neuronal degeneration.

We show that following self-assembly into stable aggregates, $\beta A P s$ induce neurodegeneration in both short-term and mature cultures. Thus, the state of $\beta$ AP assembly appears to influence their biological activities. Accordingly, solvation conditions that alter $\beta \mathrm{AP}$ conformation and assembly may also affect $\beta \mathrm{AP}$ induced degeneration. Consistent with this position, we observed that, in comparison to water-solubilized $\beta 25-35$, solubilization of $\beta 25-35$ in $35 \%$ acetonitrile, $0.1 \%$ TFA significantly reduced both its level of measurable aggregation and its neurotoxic impact. Similarly, resolubilization of aggregated $\beta 1-42$ in HFP increased the peptide's solubility and lessened its degenerative effects. Interestingly, soluble $\beta 1-42$ resolubilized in HFP induced toxicity equivalent with that caused by aggregated $\beta 1-42$ resolubilized in HFP. Combined with our other observations, this finding suggests that $\beta$ APs in solution may reach a state of equilibrium along a continuum between solubility and aggregation. The equilibrium levels of unassembled monomers (possibly in different conformations) and assembled dimers and multimers may be determined in part by the solvent (e.g., water, HFP, or $35 \%$ acetonitrile, $0.1 \%$ TFA).

Since aggregated $\beta$ APs induce neurotoxicity, other stable protein aggregates exhibiting $\beta$-sheet structure may share this property. This possibility does not weaken the theory that $\beta$ AP contributes to $\mathrm{AD}$ neurodegeneration, since it is $\beta \mathrm{AP}$, not other proteins, that is deposited within the AD brain. Regardless of this argument, the notion of a generalized aggregation-related toxicity is not supported by our data: the aggregating peptide IAP20-29 does not affect neuronal survival in the defined paradigm. Although this observation does not rule out the potential for toxicity by other aggregated proteins, it does suggest that the mechanism of aggregated $\beta$ AP-induced toxicity may be relatively specific.

The mechanism(s) responsible for the biological activities of $\beta A P s$ has not been clearly defined. Yankner and colleagues hypothesized that $\beta \mathrm{AP}$-induced effects may be mediated by a receptor pathway since equimolar addition of substance $P$ and other tachykinins blocked both trophic and toxic responses to $\beta A P$ s (Yankner et al., 1990). More recently, the serpin-enzyme complex receptor was reported to bind both $\beta A P$ s and substance $\mathrm{P}$ and thus was suggested to represent the $\beta \mathrm{AP}$ site of action (Joslin et al., 1991). However, the toxicity reported here likely results from a mechanism unrelated to the one proposed by Yankner and colleagues, since we have not observed protection against the toxicity of New $\beta 25-35$ by equimolar addition $(25$ $\mu \mathrm{M})$ of substance $\mathrm{P}(p=0.78$ by onc-way ANOVA, $n=3)$. Similarly, recent in vivo studies of $\beta \mathrm{AP}$-induced toxicity have not demonstrated protection by substance P (Rush et al., 1992; Waite et al., 1992).

Toxicity mediated by excitatory amino acids (EAAs) is a welldocumented mechanism of neurodegeneration (see Rothman and Olney, 1987; Choi, 1991) that has also been postulated to function in $\beta$ AP-induced toxicity. For example, Koh et al. (1990) reported that soluble $\beta$ APs are not directly neurotoxic to mature cortical cultures, but do potentiate EAA-mediated toxicity. A study by Copani et al. (1991) substantiated the EAA/ $\beta$ AP link by demonstrating that full-length $\beta \mathrm{AP}$ exacerbates the neurodegeneration caused by transient glucose deprivation, an EAAmediated neurotoxic event. The EAA/ $\beta$ AP toxicity relationship has been repeated and extended in a recent publication by Mattson et al. (1992). Mattson et al. also reported that $\beta$ APs increase the resting intraneuronal concentration of calcium, suggesting that the mechanism of $\beta$ APs' effects includes destabilization of calcium levels. In the present study, a similar disruption of the tightly regulated intracellular calcium levels remains a potential mechanism in the toxicity of aggregated $\beta$ APs. However, the same EAA $/ \beta$ AP toxicity relationship may not apply to the reported toxicity for the following three reasons: (1) in our shortterm culture studies toxicity is elicited during the first day in vitro, a period when hippocampal neurons are insensitive to EAA-mediated toxicity (Mattson et al., 1988); (2) EAA-mediated toxicity is accompanied by marked cellular swelling, whereas aggregation-related $\beta \mathrm{AP}$ toxicity is characterized morphologically by cellular collapse; (3) MK801, a potent inhibitor of glutamate-mediated toxicity in vitro, does not significantly attenuate $\beta 25-35$ toxicity in our long-term cultures.

Since $\beta$-amyloid exists in an insoluble, aggregated state within senile plaques, determination of how cells interact with aggregated $\beta \mathrm{APs}$ in vitro may be an important step in understanding how $\beta$-amyloid may contribute to neurodegeneration within the AD brain. Although mechanisms to account for the toxicity of soluble $\beta$ APs have been proposed, they do not appear to explain the neurodegeneration caused by aggregated $\beta$ APs. Recently, we and others have reported that the $\beta \mathrm{AP}$-induced degeneration of both short-term (Copani et al., 1992; Copani, Loo, Pike, Whittemore, Walencewicz, and Cotman, unpublished observations) and long-term (Forloni et al., 1992) neuronal cultures appears to follow an apoptotic pathway of cell death. Apoptotic degeneration involves cellular processes believed to be distinct from those occurring during necrotic cell death, which can be induced by acute excitotoxic insults (Masters et al., 1989; Ignatowics et al., 1991). Although how $\beta$ APs may trigger apoptosis is not known, we hypothesize that a death program would be stimulated by compromised cellular functions that could result from intraneuronal accumulation of aggregated $\beta$ APs. Consistent with this possibility, a recent study by Glabe and colleagues found that cultured fibroblasts uptake and collect $\beta 1-42$ within lysosomes, where it accumulates in aggregated forms but is not degraded; nonaggregating $\beta$ APs were rapidly degraded and did not accumulate intracellularly (Knauer et al., 1992).

In conclusion, we have demonstrated that hydrophobic sequences appear to be necessary for stable in vitro aggregation of $\beta \mathrm{APs}$, and that this aggregation, in turn, is associated with toxic properties of $\beta$ APs. The exact mechanism(s) responsible for the degenerative effects of aggregated $\beta$ APs remains undefined, but may ultimately involve an apoptotic pathway. We suggest that conformational changes in $\beta A P s$ promote self-assembly into insolublc aggregates and may confer quantitative and/or qualitative changes in $\beta$-amyloid's biological activities. The result may be an enhancement in the degenerative effects of $\beta$-amyloid by aggregated forms: soluble $\beta$ APs appear to induce degeneration by exacerbating other forms of toxicity whereas aggregated $\beta$ APs can induce toxicity in the absence of additional insults. Thus, in the AD brain, neurons associated with $\beta$-amyloid deposits are predicted to be vulnerable to degeneration, a risk that may be reduced by measures that can lessen or prevent the protein's self-assembly.

\section{References}

Abele AE, Scholz KP, Scholz WK, Miller RJ (1990) Excitotoxicity induced by enhanced excitatory neurotransmission in cultured hippocampal pyramidal neurons. Neuron 2:413-419.

Banker GA, Cowan WM (1977) Rat hippocampal neurons in dispersed cell culture. Brain Res 126:397-425. 
Barbin G, Selak I, Manthorpe M, Varon S (1984) Use of central neuronal culture for the detection of neuronotrophic agents. Neuroscience 12:33-43.

Barrow CJ, Zagorski MG (1991) Solution structures of $\beta$ peptide and its constituent fragments: relation to amyloid deposition. Science 253: 179-182.

Bottenstcin JH, Sato GH (1979) Growth of a rat neuroblastoma cell line in serum-free supplemented medium. Proc Natl Acad Sci USA 76:514-517.

Brewer GL, Cotman CW (1989) Survival and growth of hippocampal neurons in defined medium at low density: advantages of a sandwich culture technique or low oxygen. Brain Res 494:65-74.

Bridges RJ, Hatalski C, Shim SN, Nunn PB (1991) Gliotoxic properties of the Lathyrus excitotoxin $\beta$ - $N$-oxalyl-L- $\alpha, \beta$-diaminopropionic acid ( $\beta$-L-ODAP). Brain Res 561:262-268.

Burdick D, Soreghan B, Kwon M, Kosmoski J, Knauer M, Henschen A, Yates J, Cotman C, Glabe C (1992) Assembly and aggregation properties of synthetic Alzheimer's A4/ $\beta$ amyloid peptide analogs. J Biol Chem 267:546-554.

Chartier-Harlin M-C, Crawford F, Houlden H, Warren A, Hughes D, Fidani L, Goate A, Rossor M, Roques P, Hardy J, Mullan M (1991) Early-onset Alzheimer's disease caused by mutations at codon 717 of the $\beta$-amyloid precursor protein gene. Nature 353:844-846.

Choi DW (1991) Fast and slow excitotoxicity in cortical cell culture. In: Excitatory amino acids (Meldrum BS, Moroni F, Simon RP, Woods JH, eds), pp 555-561. New York: Raven.

Cooper GJS, Willis AC, Clark A, Turner RC, Sim RB, Reid KB (1987) Purification and characterization of a peptide from amyloid-rich pancreases of type 2 diabetic patients. Proc Natl Acad Sci USA 84:86288632.

Copani A, Koh J-Y, Cotman CW (1991) $\beta$-Amyloid increases neuronal susceptibility to injury by glucose deprivation. Neuroreport 2:763765.

Copani A, Loo DT, Pike CJ, Walencewicz AJ, Cotman CW (1992) Ncurodegencration induced by $\beta$-amyloid peptides in vitro may follow an apoptotic pathway. Soc Neurosci Abstr 18:1439.

Esch FS, Keim PS, Beattie EC, Blacher RW, Culwell AR, Oltersdorf T, McClure D, Ward PJ (1990) Cleavage of amyloid $\beta$ peptide during constitutive processing of its precursor. Science 248:1122-1124.

Forloni G, Chiesa R, Angeretti N, Smiroldo S (1992) Neurotoxicity induced by chronic application of $\beta$ amyloid fragment: involvement of apoptosis. Soc Neurosci Abstr 18:1439.

Frautschy SA, Baird A, Cole GM (1991) Effects of injected Alzheimer $\beta$-amyloid cores in rat brain. Proc Natl Acad Sci USA 88:8362-8366.

Glenner GC, Eanes ED, Wiley CA (1988) Amyloid fibrils formed from a segment of the pancreatic islet amyloid protein. Biochem Biophys Res Commun 155:608-614.

Goate A, Chartier-Harlin M-C, Mullan M, Brown J, Crawford F, Fidani L, Giuffra L, Hayncs A, Irving N, James L, Mant R, Newton P, Rooke $\mathrm{K}$, Roques $\mathrm{P}$, Talbot C, Pericak-Vance M, Roses A, Williamson R, Rossor M, Owen M, Hardy J (1991) Segregation of a missense mutation in the amyloid precursor protein gene with familial Alzheimer's disease. Nature 349:704-706.

Halverson K, Fraser PE, Kirschner DA, Lansbury JPT (1990) Molecular determinants of amyloid deposition in Alzheimer's disease: conformational studies of synthetic $\beta$-protein fragments. Biochemistry 29:2639-2644.

Hilbich C, Kisters-Woike B, Reed J, Masters CL, Beyreuther K (1991) Aggregation and secondary structure of synthetic amyloid $\beta A 4$ peptides of Alzheimer's disease. J Mol Biol 218:149-163.

Ignatowics E, Vezzani A-M, Rizzi M, D'Incalci M (1991) Nerve cell death induced in vivo by kainic acid and quinolinic acid does not involve apoptosis. Ncuroreport 2:651-654.

Joslin G, Krause JE, Hershey AD, Adams SP, Fallon RJ, Perlmutter DH (1991) Amyloid- $\beta$ peptide, substance $P$, and bombesin bind to the serpin-enzyme complex receptor. J Biol Chem 266:21897-21902.

Kang J, Lemaire H-G, Unterbeck A, Salbaum JM, Masters CM, Grzeschik K-H, Multhaup G, Beyreuther K, Muller-Hill B (1987) The precursor of Alzheimer's disease amyloid A4 protein resembles a cellsurface receptor. Nature 325:733-736.

Kirschner DA, Inouye H, Duffy LK, Sinclair A, Lind M, Selkoe DJ (1987) Synthetic peptide homologous to $\beta$ protein from Alzheimer's disease forms amyloid-like fibrils in vitro. Proc Natl Acad Sci USA 84:6953-6957.

Knauer MF, Soreghan B, Burdick D, Kosmoski J, Glabe CG (1992) Intracellular accumulation and resistance to degradation of the Al- zheimer's amyloid A4/ $\beta$ protein. Proc Natl Acad Sci USA 89:74377441.

Koh J-Y, Choi DW (1987) Quantitative determination of glutamate mediated cortical neuronal injury in cell culture by lactate dehydrogenase afflux assay. J Neurosci Methods 20:83-90.

Koh J-Y, Yang LL, Cotman CW (1990) $\beta$-Amyloid protein increases the vulncrability of cultured cortical ncurons to cxcitotoxic damage. Brain Res 533:315-320.

Kowall NW, Beal MF, Busciglio J, Duffy LK, Yankner BA (1991) An in vivo model for the neurodegenerative effects of $\beta$ amyloid and protection by substance P. Proc Natl Acad Sci USA 88:7247-7251.

Laemmli UK (1970) Cleavage of structural proteins during the assembly of the head of bacteriophage T4. Nature 227:680-685.

Masters CL, Multhaup G, Simms G, Rottgiesser J, Martins RN, Beyreuther K (1985a) Neuronal origin of a cerebral amyloid: neurofibrillary tangles of Alzheimer's disease contain the same protein as the amyloid of plaque cores and blood vessels. EMBO J 4:2757-2763.

Masters CL, Simms G, Weinman NA, Multhaup G, McDonald BL, Beyreuther K (1985b) Amyloid plaque core protein in Alzheimer disease and Down syndrome. Proc Natl Acad Sci USA 82:4245-4249.

Mastcrs JN, Finch CE, Sapolsky RM (1989) Glucocorticoid endangerment of hippocampal neurons does not involve deoxyribonucleic acid cleavage. Endocrinology 124:3083-3087.

Mattson MP, Ping D, Kater SB (1988) Outgrowth-regulating actions of glutamate in isolated hippocampal pyramidal neurons. J Neurosci 8:2087-2100.

Mattson MP, Cheng B, Davis D, Bryant K, Leieberburg I, Rydel R (1992) $\beta$-Amyloid peptides destabilize calcium homeostasis and render human cortical neurons vulnerable to excitotoxicity. J Neurosci $12: 376-389$.

McCarthy KD, de Vellis J (1980) Preparation of separate astroglial and oligodendroglial cell cultures from rat cerebral tissue. J Cell Biol 85:890-902.

Murrell J, Farlow M, Ghetti B, Benson MD (1991) A mutation in the amyloid precursor protein associated with hercditary Alzheimer's disease. Science 254:97-99.

Pike CJ, Walencewicz AJ, Glabe CG, Cotman CW (1991a) Aggregation-related toxicity of synthetic $\beta$-amyloid protein in hippocampal cultures. Eur J Pharmacol 207:367-368.

Pike CJ, Walencewicz AJ, Glabe CG, Cotman CW (1991b) In vitro aging of $\beta$-amyloid protein causes peptide aggregation and neurotoxicity. Brain Res 563:311-314.

Pike CJ, Cummings BJ, Cotman CW (1992) $\beta$-Amyloid induces neuritic dystrophy in vitro: similarities with Alzheimer pathology. Neuroreport 3:769-772.

Rondouin G, Drian M-J, Chicheportiche R, Kamenka J-M, Privat A (1988) Non-competitive antagonists of $N$-methyl-D-aspartate receptors protect cortical and hippocampal cell cultures against glutamate ncurotoxicity. Ncurosci Lett 91:199-203.

Rothman SM, Olney JW (1987) Excitotoxicity and the NMDA receptor. Trends Neurosci 10:299-302.

Rush DK, Aschimies S, Merriman MC (1992) Intracerebral $\beta$-amyloid(25-35) produces tissue damage: is it neurotoxic? Neurobiol Aging 13:591-594.

Selkoe DJ (1991) The molecular pathology of Alzheimer's disease. Neuron 6:487-498.

Selkoe DJ, Abraham CR, Podlisny MB, Duffy LD (1986) Isolation of low-molecular-weight proteins from amyloid plaque fibers in Alzheimer's disease. J Neurochem 46:1820-1834.

Tanzi RE, St. George-Hyslop PH, Gusella JF (1989) Moleculargenetic approaches to Alzheimer's disease. Trends Neurosci 12:152-158.

Waite J, Cole GM, Frautschy SA, Connor DJ, Thal LJ (1992) Solvent cffects on beta protein toxicity in vivo. Neurobiol Aging 13:595-599.

Waterborg JH, Matthews HR (1984) The Lowry method for protein determination. In: Methods in molecular biology: proteins (Walker JM, ed), pp 1-3. Clifton, NJ: Humana.

Westermark P, Wernstedt C, Wilander E, Hayden DH, O'Brien TD, Johnson $\mathrm{KH}$ (1987) Amyloid fibrils in human insulinoma and islets of Langerhans of the diabetic cat are derived from a neuropeptidelike protein also present in normal islet cells. Proc Natl Acad Sci USA 84:3881-3885.

Westermark P, Engström U, Johnson KH, Westermark GT, Betsholtz C (1990) Islet amyloid polypeptide: pinpointing amino acid residues linked to amyloid fibril formation. Proc Natl Acad Sci USA 87:50365040 .

Whitson JS, Selkoe DJ, Cotman CW (1989) Amyloid $\beta$ protein en- 
hances the survival of hippocampal neurons in vitro. Science 243 : $1488-1490$.

Whitson JS, Glabe CG, Shitani E, Abcar A, Cotman CW (1990) $\beta$-Amyloid protein promotes neuritic branching in hippocampal cultures. Neurosci Lett 110:319-324.

Wisniewski HM, Iqbal K, Bancher C, Miller D, Curie J (1989) Cy- toskeletal protein pathology and the formation of beta-amyloid fibers in Alzheimer's disease. Neurobiol Aging 10:409-412.

Yankner BA, Duffy LK, Kirschner DA (1990) Neurotrophic and neurotoxic effects of amyloid $\beta$ protein: reversal by tachykinin neuropeptides. Science 250:279-282. 